\title{
Centimeter of Water per Milliliter
}

National Cancer Institute

\section{Source}

National Cancer Institute. Centimeter of Water per Milliliter. NCI Thesaurus. Code C135520.

A unit of measure for pressure change that is expressed in $\mathrm{cmH} 2 \mathrm{O}$ per milliliter. 